J. Clin. Chem. Clin. Biochem.

Vol. 18,1980 , pp. $781-788$

\title{
A New Spectrophotometric Method for the Determination of $5^{\prime}$-Nucleotidase ${ }^{1}$ )
}

By F. Heinz, Renate Pilz, Sylvia Reckel,

Zentrum Biochemie, Medizinische Hochschule Hannover

J. R. Kalden,

Institut und Poliklinik für Klinische Immunologie der Universität Erlangen-Nürnberg and

\section{R. Haeckel}

Institut für Klinische Chemie, Medizinische Hochschule Hannover

(Received March 4/June 19, 1980)

Summary: A spectrophotometric method is described for the determination of $5^{\prime}$-nucleotidase.

In combination with the enzymes nucleoside phosphorylase and xanthine oxidase, inosine, formed by hydrolysis of $5^{\prime}$-LMP by $5^{\prime}$-nucleotidase, is cleaved phosphorolytically to hypoxanthine, which is oxidized to uric acid. In the presence of ethanol, the hydrogen peroxide formed is reduced by catalase and equivalent amounts of acetaldehyde are produced. The aldehyde is dehydrogenated (NADP-dependent) by aldehyde dehydrogenase and the production rate of NADPH is recorded at $334 \mathrm{~nm}$. The inhibition of the unspecific cleavage of $5^{\prime}$-IMP by phosphatases is examined critically.

\section{Eine neue spektrophotometrische Methode zur Bestimmung von 5'-Nucleotidase}

Zusammenfassung: Eine spektrophotometrische Methode für die Bestimmung der $5^{\prime}$-Nucleotidaseaktivität wird beschrieben.

In Kombination mit den Enzymen Nucleosidphosphorylase und Xanthinoxidase wird Inosin, das bei der Hydrolyse von 5'-IMP durch die 5'-Nucleotidase entsteht, phosphorolytisch zu Hypoxanthin gespalten, das weiter zu Harnsäure oxidiert wird. Das entstandene Wasserstoffperoxid wird mit Katalase in Gegenwart von Ethanol reduziert. Dabei entstehen äquimolare Mengen an Acetaldehyd. Der Aldehyd wird NADP-abhängig durch die Aldehyddehydrogenase dehyḍriert und das gebildete NADPH bei $334 \mathrm{~nm}$ automatisch registriert. Die Inhibierung der unspezifischen 5'-IMPHydrolyse wird kritisch untersucht.

\section{Introduction}

5 -nucleotidases catalyże the hydrolysis of nucleoside- $5^{\prime}$ : monophosphates to nucleosides and inorganic phosphate.

$5^{\prime}$ =nucleotidase activity has been detected in a great number of human and animal tissues $(1,2)$.

The activity present in sera is released mainly from the membrane of liver cells by bile salts and can be used as

1) This work contains part of the dissertation of Renate Pilz, Medizinische Hochschule Hannover.

Parts were presented at the FEBS Special Meeting on Enzymes, Dubrovnik-Cavtat 1979. a marker for liver disease (1). Elevated enzyme levels are detectable in sera particularly if the hepatobiliary tract is involved; generally, the rise in $5^{\prime}$-nucleotidase activity is accompanied by that of alkaline phosphatase, glutamyltransferase and other marker enzymes for liver disease. However, alkaline phosphatase is also elevated in some bone diseases and during normal pregnancy, whereas $5^{\prime}$-nucleotidase remains unaltered under these conditions (1).

The diagnostic value of $5^{\prime}$-nucleotidase is still under discussion, but the enzyme has been shown to be superior to other liver enzymes, especially in cases of liver metastasis $(1,3,4,5)$. 
For the determination of $5^{\prime}$-nucleotidase activity, the following methods have been described:

For the detection of especially low activities, radioactive methods with ${ }^{14} \mathrm{C},{ }^{3} \mathrm{H}$ and ${ }^{32} \mathrm{P}$ labelled nucleoside- $5^{\prime}$-monophosphates, particularly $5^{\prime}$-AMP, are used, but special equipment is needed $(6,7,8)$.

One of the oldest methods uses the determination of inorganic phosphate liberated from the substrate according to Fiske-Subbarow $(9,10)$. This method has been adapted to automation (11) and modified by several authors $(12,13,14,15)$.

With $5^{\prime}$-AMP as substrate, the reaction product adenosine can be deaminated to inosine by coupling with the adenosine deaminase reaction, and the disappearance of adenosine is measured at $265 \mathrm{~nm}(8,16$, $17,18)$. The ammonia formation can be determined by the Berthelot reaction $(19,20,21,22,23)$ or kinetically by coupling with the glutamate dehydrogenase reaction $(24,25,26,27,28)$.

Considerable problems occur with the high absorbances of the substrate and the serum samples at $265 \mathrm{~nm}$, and the high blanks caused by ammonia normally present in sera.

With $5^{\prime}$-IMP as the substrate, the reaction product inosine can be converted to urate by the coupled nucleoside phosphorylase and xanthine oxidase reactions which may be monitored at $293 \mathrm{~nm}$ (29), but at this wavelength, the serum samples exhibit high absorbances.

We describe a simple kinetic assay with $5^{\prime}$-IMP as the substrate, using the following reaction sequence:

(1) inosine- $-5^{\prime}-P+\mathrm{H}_{2} \mathrm{O} \stackrel{5^{\prime} \text {-nucleotidase }}{\longrightarrow}$ inosine $+P_{\mathrm{i}}$

(2) inosine $+P_{i} \stackrel{\begin{array}{l}\text { nucleoside } \\ \text { phosphorylase }\end{array} \text { hypoxanthine }}{\longrightarrow}$ + ribose-1-P

xanthine

(3) hypoxanthine $+2 \mathrm{H}_{2} \mathrm{O}+2 \mathrm{O}_{2} \stackrel{\text { oxidase }}{\longrightarrow}$ uric acid $+2 \mathrm{H}_{2} \mathrm{O}_{2}$

(3) $2 \mathrm{H}_{2} \mathrm{O}_{2}+2$ ethanol $\stackrel{\text { catalase }}{\longrightarrow} 2$ acetaldehyde $+4 \mathrm{H}_{2} \mathrm{O}$

(5) 2 aldehyde $+2 \mathrm{NADP}^{+}+2 \mathrm{H}_{2} \mathrm{O} \stackrel{\text { dehydrogenase }}{\longrightarrow}+2 \mathrm{NADPH}$ $+2 \mathrm{H}^{+}$

Sum:

$$
\begin{gathered}
\text { inosine }-5^{\prime}-P+2 \mathrm{NADP}^{+} \\
+2 \text { ethanol }+2 \mathrm{O}_{2}
\end{gathered} \rightarrow \begin{gathered}
\text { uric acid }+ \text { ribose- } 1-P \\
+2 \text { acetic acid } \\
+2 \mathrm{NADPH}+2 \mathrm{H}^{+}
\end{gathered}
$$

Reaction (4) and (5) were described originally for the determination of uric acid in human serum $(30,31)$ and later for the measurement of several other substances (32) and enzymes of purine metabolism. $(33,34)$.

A special problem of 5 -nucleotidase assay derives from the interference of alkaline phosphatase. Different possibilities for the elimination of this interference are analyzed critically.

\section{Materials and Methods}

\section{Sera}

Sera were used from patients with liver diseases (containing high 5 '-nucleotidase and high alkaline plosphatase activities), from patients with bone disease, and from healthy persons. All sera were stored overnight at $4{ }^{\circ} \mathrm{C}$.

\section{Reagents}

\section{Stock solutions}

NADP (Boehringer Mannheim 128031; $12 \mathrm{mmol} / \mathrm{l}$ ): $10 \mathrm{mg}$ were dissolved in $1 \mathrm{ml}$ bidist. water.

NAD (Boehringer Mannheim 127302; $15 \mathrm{mmol} / \mathrm{l}$ ): $10 \mathrm{mg}$ were dissolved in $1 \mathrm{ml}$ bidist. water.

Magnesium chloride (Merck 5833): $1 \mathrm{~mol} / \mathrm{l}$.

Manganese-II-chloride (Merck 5927): $1 \mathrm{~mol} / 1$.

Glycerol-2-phosphate (disodium salt, Sigma G-6521): $1 \mathrm{~mol} / \mathrm{l}$, adjusted to $\mathrm{pH} 7.5$.

$R 8231^{2}$ ) (Janssen, Düsseldorf): $33.9 \mathrm{mg}$ were dissolved in $1 \mathrm{ml}$ $0.1 \mathrm{~mol} / 1$ triethanolamine buffer (Boehringer Mannheim

127426) pH 7.5 containing $0.1 \mathrm{~mol} / 1 \mathrm{KCl}$ (Merck 4936).

Dithioerythritol (Merck 24511;1 mmol/1): $1.54 \mathrm{mg}$ dithioery thritol were dissolved in $10 \mathrm{ml} \mathrm{H}_{2} \mathrm{O}$ bidist.

Inosine-5'-monophosphate (Boehringer Mannheim 106704; $40 \mathrm{mmol} / \mathrm{l}$ ): $5 \mathrm{mg}$ were dissolved in $0.25 \mathrm{ml} 0.1 \mathrm{~mol} / 1$ triethanolamine buffer $\mathrm{pH} 7.5$ containing $0.1 \mathrm{~mol} / 1 \mathrm{KCl}$.

Adenosine-5'-monophosphate (Boehringer Mannheim 102199; $40 \mathrm{mmol} / \mathrm{l}$ ): $5 \mathrm{mg}$ were dissolved in $0.25 \mathrm{ml} 0.1 \mathrm{~mol} / 1 \mathrm{tri}-$ ethanolamine buffer $\mathrm{pH} 7.5$ containing $0.1 \mathrm{~mol} / \mathrm{l} \mathrm{KCl}$.

\section{Buffer-mixture}

To a mixture of $9 \mathrm{ml} 0.1 \mathrm{~mol} / 1$ triethanolamine buffer $\mathrm{pH} 7.5$ containing $0.1 \mathrm{~mol} / 1 \mathrm{KCl}$ and $1 \mathrm{ml}$ ethanol (Merck 972) were added $0.01 \mathrm{ml}$ catalase suspension (EC 1.11.1.6; Boehringer Mannheim 106 810; $10 \mathrm{mg} / \mathrm{ml}$; ca. 13000 U) $5 \mathrm{mg} \mathrm{NADP,}$ $135 \mathrm{mg}$ glycerol-2-phosphate (disodium salt), $0.02 \mathrm{ml}$ of $1 \mathrm{~mol} / \mathrm{l}$ potassium dihydrogenphosphate (Merck 4873) and $0.1 \mathrm{ml}$ of $1 \mathrm{~mol} / 1$ magnesium chloride (Merck 5833). $\mathrm{pH}$ was readjusted to 7.5 .

\section{Enzymes}

Aldehyde dehydrogenase (EC 1.2.1.5; Sigma A-6758): $10 \mathrm{mg}$ of the lyophilized powder (ca. $5 \mathrm{mg}$ protein) were dissolved in $1 \mathrm{ml} \mathrm{H}_{2} \mathrm{O}$ (ca. $50 \mathrm{U} / \mathrm{ml}$ ). If necessary to remove phosphate, the enzyme was dissolved in $0.1 \mathrm{~mol} / 1$ triethanolamine buffer pH 7.5 containing $0.1 \mathrm{~mol} / 1 \mathrm{KCl}$ and glycerol $3 \mathrm{~mol} / 1$ and dialyzed overnight at $4^{\circ} \mathrm{C}$ against the same solution. The dialyzed enzyme was stable for one week at $4^{\circ} \mathrm{C}$.

Xanthine oxidașe (EC 1.2.3.2; Boehringer Mannheim 110442; $10 \mathrm{mg} / \mathrm{ml}$; ca. $0.4 \mathrm{U} / \mathrm{mg})$ : For elimination of $\left(\mathrm{NH}_{4}\right)_{2} \mathrm{SO}_{4}$, which produces magnesium ammonium phosphate precipitation, the enzyme suspension was dialyzed overnight at $4^{\circ} \mathrm{C}$ against

$0.1 \mathrm{~mol} / \mathrm{l} \mathrm{KCl}$. The dialyzed enzyme showed an activity of about $3 \mathrm{U} / \mathrm{ml}$ and was stable for one week at $4^{\circ} \mathrm{C}$.

2) $D, L-6(m$-bromophenyl)-5,6-dihydroimidazo(2;1-b)thiażole oxalate. 
Nucleoside phosphorylase (EC 2.4.2.1; Boehringer Mannheim $107964 ; 5 \mathrm{mg} / \mathrm{ml}$; ca. $20 \mathrm{U} / \mathrm{mg}$ ): If necessary, the enzyme suspension was dialyzed phosphate-free overnight at $4{ }^{\circ} \mathrm{C}$ against $0.1 \mathrm{~mol} / 1$ trie thanolamine buffer containing $0.1 \mathrm{~mol} / 1$ $\mathrm{KCl}$ and glycerol $3 \mathrm{~mol} / 1$ (stable for ten days at $4^{\circ} \mathrm{C}$ ).

Adenosine deaminase (EC 3.5.4.2; Boehringer Mannheim $102121 ; 10 \mathrm{mg} / \mathrm{ml} ; 200 \mathrm{U} / \mathrm{mg}$ ): The suspension was used without further dilution.

\section{Antibodies}

$\mathrm{NaCl}$-polyethyleneglycol-solution: $0.15 \mathrm{~mol} / 1 \mathrm{NaCl}$ containing $6 \%$ polyethyleneglycol 6000 (Serva 33137 ).

Anti-alkaline phosphatase from liver/bone (Merck 13772): $10 \mathrm{mg}$ lyophilized powder were dissolved in $1 \mathrm{ml} \mathrm{NaCl}$-polyethyleneglycol solution.

\section{Instrumentation}

In the manual versions, the $\mathrm{NAD}(\mathrm{P}) \mathrm{H}$ reduction rates were measured in an Eppendorf photometer at $\mathrm{Hg} 334 \mathrm{~nm}$ at $30^{\circ} \mathrm{C}$. The change in absorbance was registered continuously. The mechanized version was performed with a Gemsaec analyzer (ElectroNucleonics, Stuttgart).

The determination of alkaline phosphatase activity was performed with an. Eppendorf photometer at $\mathrm{Hg} 405 \mathrm{~nm}$. The absorbance at $690 \mathrm{~nm}$, used for the determination of phosphate in the test system according to Campbell (11) and Rieder (10), was measured with a spectrophotometer Zeiss PMQ-II.

\section{Methods}

\section{$5^{\prime}$-Nucleotidase}

For optimisation experiments, the reagents listed in table 1 were pipetted into a semimicro-cuvette with $10 \mathrm{~mm}$ optical path-length, thoroughly mixed, and incubated for 15 minutes at $30^{\circ} \mathrm{C}$. During this time, the reaction temperature was reached and traces of acetaldehyde present in the ethanol were dehydrogenated. Then a small linear rise of absorbance was registered at $334 \mathrm{~nm}$, which represents the blank and has to be subtracted. The reaction was started by the addition of 5 '-IMP. After a lag period of one to three minutes, depending on the 5 -nucleotidase activity, a linear rise of absorbance for at least 10 minutes was observed.

If one of the components was varied, a calculated volume of a stock solution was added to the mixture lacking this particular component. Thus, manganese replaced the magnesium ion, R 8231 the glycerol-2-phosphate, and NAD replaced NADP or was added additionally.

For routine application in clinical chemistry in the manual and mechanical version, dithioery thritol, which stabilizes the aldehyde dehydrogenase, was omitted and EDTA was added. In this case, the magnesium concentration had to be elevated. For simplification, the enzymes were added to the buffer mixture. The test composition, shown in table 2, is stable for $6 \mathrm{~h}$ in an ice bath.

\section{Alkaline phosphatase}

Alkaline phosphatase was measured using the test kit "alk. Phosph. opt." from Boehringer Manniheim (123 862), but the reaction temperature was kept at $30^{\circ} \mathrm{C}$.

\section{Precipitation of alkaline phosphatase by antibodies}

$0.5 \mathrm{ml}$ serum were incubated with $0.025 \mathrm{ml}$ dissolved antibodies (sufficient for at least $1 \mathrm{U}$ alkaline phosphatase) and $0.475 \mathrm{ml}$ $\mathrm{NaCl}$-polyethylenegly col-solution for $1 \mathrm{~h}$ at $37^{\circ} \mathrm{C}$ and then stored for $16-18 \mathrm{~h}$ at $4^{\circ} \mathrm{C}$. After centrifugation, the supernatant was tested for alkaline phosphatase activity. For the control, $0.5 \mathrm{ml}$ of the same serum were mixed with $0.5 \mathrm{ml}$ $\mathrm{NaCl}$-polyethyleneglycol solution and treated identically.

\section{Absorption coefficients \\ For NADPH, the molar absorption coefficient $\left(\epsilon_{334} \mathrm{~nm}\right)$ of $6.18 \times 10^{2}\left(1 \cdot \mathrm{mol}^{-1} \cdot \mathrm{mm}^{-1}\right)$ and for $p$-nitrophenol $\left(\epsilon_{405} \mathrm{~nm}\right)$}

Tab. 1. Reaction mixture for optimisation-experiments.

\begin{tabular}{|c|c|c|c|}
\hline Reagents & $\mu l$ & $\begin{array}{l}\text { Concentration } \\
\text { in the assay }\end{array}$ & $\begin{array}{l}\text { Activities } \\
\text { under } \\
\text { present } \\
\text { condi- } \\
\text { tions }\end{array}$ \\
\hline
\end{tabular}

Buffer-reagent-mixture:

$\begin{array}{ll}9 \mathrm{ml} 0.1 \mathrm{~mol} / 1 & 0.09 \mathrm{~mol} / \mathrm{l} \\ \text { triethanolamine, } \mathrm{pH} 7.5, & 0.09 \mathrm{~mol} / \mathrm{l} \\ \text { containing } 0.1 \mathrm{~mol} / 1 \mathrm{KCl} & 1.7 \mathrm{~mol} / 1\end{array}$

$1 \mathrm{ml}$ ethanol

$1.7 \mathrm{~mol} / \mathrm{l}$

$0.01 \mathrm{ml}$ catalase

$(10 \mathrm{mg} / \mathrm{ml})$

$13000 \mathrm{U}$

$5 \mathrm{mg}$ NADP 400

$0.64 \mathrm{mmol} / \mathrm{l}$

$135 \mathrm{mg}$ glycerol-2-

phosphate, disodium salt

$0.02 \mathrm{ml}$ potassium

phosphate $(1 \mathrm{~mol} / \mathrm{l})$

$0.043 \mathrm{~mol} / 1$

$0.1 \mathrm{ml}$ magnesium

chloride ( $1 \mathrm{~mol} / \mathrm{l})$

$0.002 \mathrm{~mol} / 1$

$0.01 \mathrm{~mol} / 1$

Dithioerythritol

$0.01 \mathrm{mmol} / 1$

(1 $\mathrm{mmol} / \mathrm{l}$ )

Aldehyde dehydrogenase (10 $\mathrm{mg} / \mathrm{ml})$

Xanthine oxidase

(10 $\mathrm{mg} / \mathrm{ml}$, dialyzed)

Nucleoside phosphorylase

5

$0.25 \mathrm{U}$ ( $5 \mathrm{mg} / \mathrm{ml}$ )

Sample

Incubate for $15 \mathrm{~min}$, after registration of the blank, start with Inosine-5'-monophosphate $5 \quad 0.4 \mathrm{mmol} / \mathrm{l}$ $(0.04 \mathrm{~mol} / \mathrm{l})$

of $18.5 \times 10^{2}\left(1 \cdot \mathrm{mol}^{-1} \cdot \mathrm{mm}^{-1}\right)$ according to Walter et al (35) were used.

\section{Enzyme units}

The enzyme activities are expressed in international units (U). 1 U 5'-nucleotidase represents the disappearance of $1 \mu$ mole of $5^{\prime}$-IMP, and $1 \mathrm{U}$ of alkaline phosphatase the splitting of $1 \mu \mathrm{mole}$ of $p$-nitrophenylphosphate per minute at $30^{\circ} \mathrm{C}$. For comparison with our method, a commercially available test kit ( $5^{\prime}$-nucleotidase, Biomérieux 6-1251 and 6-1261) was used. The determination and calculation were carried out according to the manufacturer.

\section{Results and Discussion}

\section{Choice of substrates}

In general, $5^{\prime}$-AMP is used as a substrate for $5^{\prime}$-nucleotidase. We prefer $5^{\prime}$-IMP at a final concentration of $0.4 \mathrm{mmol} / \mathrm{l}$, because the same $K_{\mathrm{m}}$-values of $0.03 \mathrm{mmol} / \mathrm{l}$ were found for $5^{\prime}$-IMP and $5^{\prime}$-AMP, and the maximal velocities were also identical. However, in the case of 5 -AMP, an extra $2 \mathrm{U}$ of adenosine deaminase had to be added to the test system. 
Tab. 2. Reaction mixture for the manual and mechanized version in rou tine application.

\begin{tabular}{|c|c|c|c|}
\hline Reagents & $\mu l$ & $\begin{array}{l}\text { Concentration } \\
\text { in the assay }\end{array}$ & $\begin{array}{l}\text { Activities } \\
\text { under } \\
\text { present } \\
\text { condi- } \\
\text { tions }\end{array}$ \\
\hline
\end{tabular}

Buffer-reagent-mixture:

$9 \mathrm{ml} 0.1 \mathrm{~mol} / \mathrm{l}$

trie thanolamine, $\mathrm{pH} 7.5$,

containing $0.1 \mathrm{~mol} / 1 \mathrm{KCl}$

and $1 \mathrm{mmol} / \mathrm{l}$ EDTA

$1 \mathrm{ml}$ ethanol

$0.09 \mathrm{~mol} / \mathrm{l}$

$0.01 \mathrm{ml}$ catalase

$(10 \mathrm{mg} / \mathrm{ml}$ )

$5 \mathrm{mg}$ NADP

$135 \mathrm{mg}$ glycerol-2-

phosphate, disodium salt

$0.02 \mathrm{ml}$ potassium

phosphate $(1 \mathrm{~mol} / \mathrm{l})$

$0.15 \mathrm{ml}$ magnesium

chloride (1 mol/l)

$7 \mathrm{mg}$ aldehyde

dehydrogenase

$0.14 \mathrm{ml}$ nucleoside

phosphorylase $(5 \mathrm{mg} / \mathrm{ml}$ )

450

$0.043 \mathrm{~mol} / 1$

$0.9 \mathrm{mmol} / \mathrm{l}$

$1.7 \mathrm{~mol} / 1$

$13000 \mathrm{U}$

$1 \mathrm{ml}$ xanthine oxidase

$(10 \mathrm{mg} / \mathrm{ml})$, dialyzed

overnight against

$0.1 \mathrm{~mol} / 1 \mathrm{KCl}$

'Sample

Start with

Inosine-5'-mono-

phosphate $(0.04 \mathrm{~mol} / \mathrm{l})$

5

$0.4 \mathrm{mmol} / \mathrm{l}$

Respectively blank with

Water

5

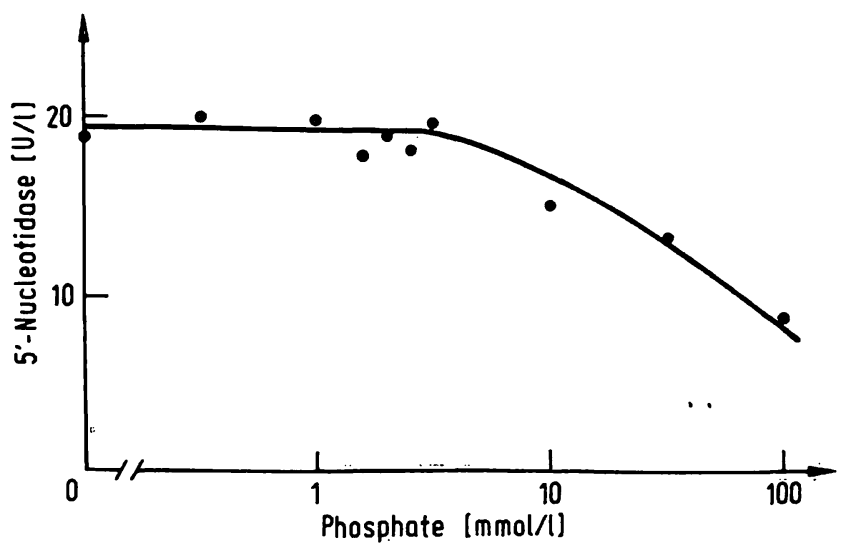

Fig. 1. Influence of phosphate on the activity of 5 -nucleotidase. Known amounts of phosphate were added to the test system of table 1 . The activity of nucleoside phosphorylase, even in the samples with the lowest phosphate content, was not rate limiting.

\section{pH-optimum}

The optimal $\mathrm{pH}$, reported by most authors between 7.2 and $7.9(11,13,23,25,27)$ was found to be 7.5 in our assay with a plateau of activity between 7.25 and 7.75.

\section{Influence of phosphate}

For optimisation, it was necessary to establish the influence of phosphate; purine nucleoside phosphorylase needs phosphate as a substrate, whereas phosphate inhibits 5 '-nucleotidase.

The results shown in figure 1 demonstrate that 5 -nucleotidase present in a constant volume of serum is not inhibited by up to $5 \mathrm{mmol} / \mathrm{l}$ phosphate. At a concentration of $3 \mathrm{mmol} / \mathrm{l}$ phosphate, the nucleoside phosphorylase possesses $50 \%$ of the normal activity. For this reason, a total of $3 \mathrm{mmol} / \mathrm{l}$ phosphate was chosen, so that even in the case of elevated phosphate levels in sera or tissue extracts, $5^{\prime}$ 'nucleotidase would not be inhibited.

\section{Choice of the coenzyme}

$0.3 \mathrm{U}$ The potassium-dependent aldehyde dehydrogenase from yeast accepts NAD and NADP as coenzymes.

$0.1 \mathrm{U} \quad$ According to Ellis et al (26), the NADH-dependent test system with glutamate dehydrogenase gives only $65 \%$ of the activity obtained by measurement at $265 \mathrm{~nm}$ (18). We therefore examined the influence of NAD, NADP, NADH and NADPH.

Figure 2 shows the dependence of the 5 -nucleotidase activity on NAD and NADP, when the coenzymes were added separately. NADP-concentrătions from $0.63 \mathrm{mmol} / 1$ to $1.89 \mathrm{mmol} / 1$ do not influence the 5 -nucleotidase activity, whereas increasing amounts of NAD from $0.11 \mathrm{mmol} / 1$ to $2.25 \mathrm{mmol} / \mathrm{l}$ cause increasing inhibition. If NAD, NADH or NADPH were added to the NADPcontaining test system, only NAD and NADH were found to be inhibitors.

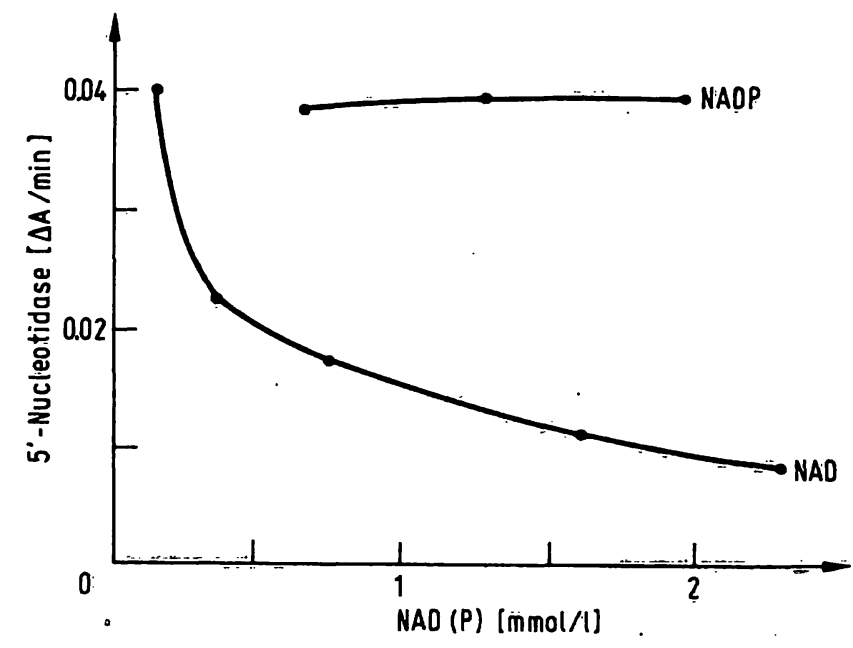

Fig. 2. Influence of NAD and NADP on the activity of 5 '-nucleotidase. Different amounts of NAD and NADP were added to the têst system of table 1 . 
As in the assay for nucleoside phosphorylase, based on the same test principle (34), no differences between NAD and NADP is observed, the decrease of activity in the $5^{\prime}$-nucleotidase assay is not due to an inhibition of the indicator enzymes.

\section{Influence of divalent cations}

The activity of 5 -nucleotidase is dependent on divalent cations. Manganese and magnesium are reported to be the best activators $(16,27,36)$.

With magnesium ions a plateau of maximal activity is reached at concentrations higher than $10 \mathrm{mmol} / 1$.

Manganese is even more effective and would increase the sensitivity of our method, but difficulties occur with the low solubility of manganese phosphate. To introduce manganese in concentrations up to the optimum of $1 \mathrm{mmol} / \mathrm{l}$, it is necessary to lower the phosphate concentration to $0.1 \mathrm{mmol} / 1$. In this case, all indicator enzymes have to be dialyzed phosphate-free and the amount of nucleoside phosphorylase has to be increased six-fold for the same test capacity.

The manganese method cannot be recommended for the determination of 5'-nucleotidase in sera, as the sensitivity with magnesium is high enough even in sera of healthy persons. However, it is necessary for the determination of 5 -nucleotidase in lymphocyte extracts (37).

\section{Prevention of 5'-IMP hydrolysis by unspecific phosphatases}

One of the critical points in the determination of $5^{\prime}$-nucleotidase activity is the unspecific splitting of nucleoside-5'-monophosphates, which is reported to be caused by alkaline phosphatase present in sera and tissue extracts. Several methods have been described to bypass this difficulty.

$5^{\prime}$-nucleotidase may be inhibited by nickel ions $(10,11$, $15)$, concanavalin $A(22,23)$ or $\alpha, \beta$-methyleneadenosine- $5^{\prime}$-diphosphate (6), and the activity may be calculated by the difference in the presence and absence of the inhibitor. The use of nickel ions as a "specific" inhibitor for $5^{\prime}$-nucleotidase has already been criticized by several authors $(5,14,16)$, because the activity of alkaline phosphatase from serum (14) and human bone (38) was found to be considerably effected by nickel ions. The same is said for $\alpha, \beta$-methyleneadenosine- 5 diphosphate (23). In our hands, the addition of concanavalin $\mathbf{A}$ to our test system containing the serum sample caused a precipitate probably due to glycoproteins änd was not suitable for a spectrophotometric assay.

Alternatively, the activity of alkaline phosphatase may be inhibited by $L$-amino acids such as $L$-histidine (36, $38,39), L$-cysteine $(14,39)$ or $L$-glycine $(7,40)$. The influecne of amino acids is obscure, as detailed studies have only been described for bull seminal plasma (36, 38).

Another possibility for the elimination of nucleoside- $5^{\prime}$ monophosphate hydrolysis is the simultaneous determination of alkaline phosphatase at $\mathrm{pH} 7.5$ with $2^{\prime}$-AMP and $3^{\prime}$-AMP as substrates, or at $\mathrm{pH} 9.8$ with $p$-nitrophenylphosphate, from which the interference of alkaline phosphatase with the $5^{\prime}$-nucleotidase assay can be calculated using an empirical correction factor (16).

Furthermore, the technique of "enzyme diversion" according to Belfield \& Goldberg (41) may be applied where high concentrations of glycerol-2-phosphate are offered to the alkaline phosphatase resulting in a competitive displacement of the nucleoside- $5^{\prime}$-monophosphate from the active center; phenylphosphate may substitute for glycerol-2-phosphate (11), but there is no advantage (41). Among these possibilities, we chose first the technique of "enzyme diversion". Figure 3 shows some typical results with a serum of a patient suffering from liver disease. Identical figures were obtained with sera of patients suffering from bone diseases with high osteoblastic activity.

Our results agree well with the findings of Belfield et al. $(19,41,42)$ and Ellis et al. (26). For further experiments, we chose a concentration of $43 \mathrm{mmol} / 1$ glycerol2-phosphate, corresponding to a 100 -fold excess over 5 -IMP.

The phosphate production from glycerol-2-phosphate by unspecific phosphatases during the incubation period and during the test time, which might have an inhibitory effect on $5^{\prime}$-nucleotidase (see figure 1 ), is negligible. According to Beckman et al. (16) we can estimate the phosphate production by a $100 \mu \mathrm{l}$ sample of pathologic serum containing $1000 \mathrm{U} / 1$ alkaline phosphatase at $50 \mathrm{nmol} / \mathrm{l}$ phosphate after 15 minutes.

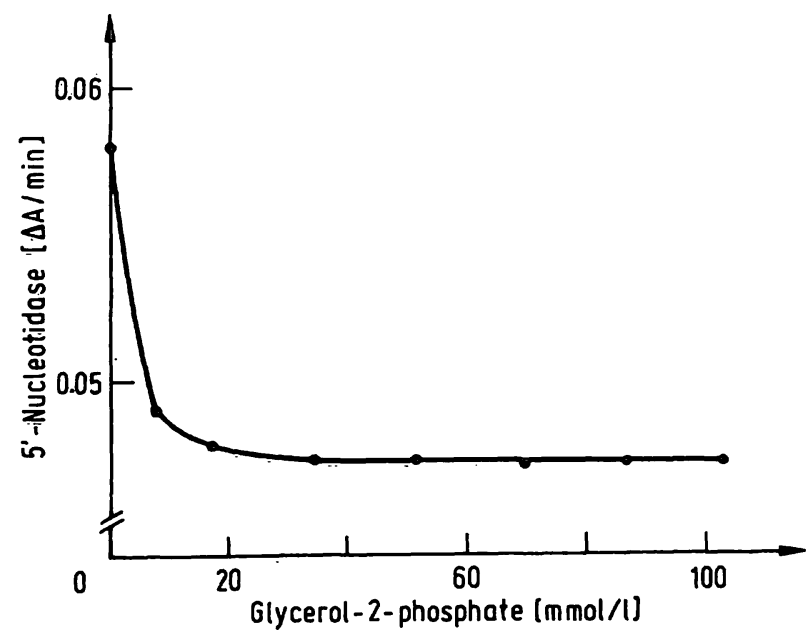

Fig. 3. Inhibition of unspecific phosphatase activity by glycerol2-phosphate.

Known amounts of glycerol-2-phosphate were added to the test system of table 1 , which contains a serum sample with high activity of alkaline phosphatase. 
The commercial availability of sheep antibodies against human alkaline phosphatase from liver and bone offers the possibility of a specific elimination of the interfering alkaline phosphatase. By treatment of sera containing high activities of alkaline phosphatase with antibodies, the activity was reduced to $1-20 \%$. Table 3 shows the results for a selection of sera. Of course, the treatment with antibodies reduces the unspecific hydrolysis of 5'-IMP at $\mathrm{pH}$ 7.5. However, the addition of glycerol-2-phosphate to antibody-treated sera reduces the hydrolysis even further, an effect, which could no longer be explained by the small residual activity of alkaline phosphatase. In the presence of glycerol-2phosphate, $5^{\prime}$-IMP hydrolysis was nearly identical in antibody-treated and untreated sera.

A new possibility for the very specific and effective inhibition of alkaline phosphatase is the application of the anthelmintic levamisole analogue $R 8231(43,44)$. With R 8231 in a concentration of $3 \mathrm{mmol} / \mathrm{l}$, we could block the alkaline phosphatase activity at $\mathrm{pH} 9.8$ in sera almost completely (99\%). In our test system, we found a reduction of total 5'-IMP hydrolysis at $\mathrm{pH} 7.5$ with $R 8231$ corresponding well to the diminution of 5 '-IMP hydrolysis after antibody elimination of alkaline phosphatase.

From the data cited above, we assume that the unspecific 5'-IMP hydrolysis at $\mathrm{pH} 7.5$ is not only caused by alkaline phosphatase, but may be due to other phosphatases, e.g. acid prostatic phosphatase, present in sera, the activity of which was eliminated by glycerol-2phosphate. For this reason, we prefer the technique of "enzyme diversion" with glycerol-2-phosphate.

Tab. 3. Influence of glycerol-2-phosphate before and after treatment of sera with anti-alkaline phosphatase from liver/ bone.

\begin{tabular}{|c|c|c|c|c|}
\hline \multirow[b]{2}{*}{$\begin{array}{l}\text { Alkaline phosphatase } \\
\text { before antibodies }\end{array}$} & \multicolumn{2}{|c|}{$\begin{array}{l}\text { Activities } \\
\text { (U/1) }\end{array}$} & \multirow[b]{2}{*}{3500} & \multirow[b]{2}{*}{1075} \\
\hline & 1300 & 280 & & \\
\hline $\begin{array}{l}\text { Alkaline phosphatase } \\
\text { after antibodies }\end{array}$ & 10 & 48 & 126 & 5 \\
\hline Difference & 1290 & 232 & 3374 & 1070 \\
\hline \multicolumn{5}{|l|}{$\begin{array}{l}5^{\prime} \text {-Nucleotidase } \\
\text { before antibodies }\end{array}$} \\
\hline Without giycerol-2-P & 6.4 & 10.2 & 40.3 & 2.0 \\
\hline Glycerol-2-P added & 4.8 & 9.5 & $36.8^{\circ}$ & 0.5 \\
\hline Difference \pm glycerol- $2-P$ & 1.6 & 0.7 & 3.5 & 1.5 \\
\hline \multicolumn{5}{|l|}{$\begin{array}{l}5^{\prime} \text {-Nucleotidase } \\
\text { after antibodies }\end{array}$} \\
\hline Without glycerol-2-P & 5.2 & 9.8 & 37.6 & 0.5 \\
\hline Glycerol-2-P added & 4.8 & 9.3 & 37.2 & 0.4 \\
\hline Difference \pm gly cerol- $2-P$ & 0.4 & 0.5 & 0.4 & 0.1 \\
\hline
\end{tabular}

Tab. 4. The within-run imprecision of the determination of the catalytic 5 '-nucleotidase activity $(n=10)$.

\begin{tabular}{lcc}
\hline & $\begin{array}{l}\text { I } \\
\text { (sample } \\
\text { blank) }\end{array}$ & $\begin{array}{l}\text { II }^{1} \text { ) } \\
\text { ( + }+ \\
\text { substrate) }\end{array}$ \\
\hline Manual procedure & & \\
Mean value (U/1) & 0.92 & 12.8 \\
Standard deviation (U/1) & 0.45 & 0.85 \\
CV $^{2}$ ) (\%) & 48.6 & 6.6 \\
Mean value (U/1) & 0.14 & 3.05 \\
Standard deviation (U/1) & 0.31 & 0.30 \\
CV (\%) & 22.1 & 9.7 \\
& & \\
Mechanized procedure (Gemsaec) & & \\
Mean value (U/1) & 1.48 & 12.75 \\
Standard deviation (U/1) & 0.11 & 0.38 \\
CV (\%) & 7.6 & 3.0 \\
Mean value (U/1) & 0.39 & 3.25 \\
Standard deviation (U/1) & 0.11 & 0.11 \\
CV (\%) & 28.2 & 3.3 \\
\hline
\end{tabular}

1) Individual sample blank subtracted

2) $\mathrm{CV}$, coefficient of variation

\section{Precision}

Several series of ten determinations were performed with human serum samples manually and with a Gemsaec analyzer. The coefficient of variation varied between 3.0 and $9.7 \%$ (tab. 4).

\section{Detection limit}

The minimal enzyme activity detectable with our method is $0.05 \mathrm{U}$ in a cuvette volume of $0.6 \mathrm{ml}$ corresponding to $0.24 \mathrm{U} / 1$ sample if $0.2 \mathrm{ml}$ of sample was added.

\section{Linearity}

Figure 5 shows a linear correlation between the amount of sample added and the change of absorbance up to $0.04 \Delta \mathrm{A} / \mathrm{min}$.

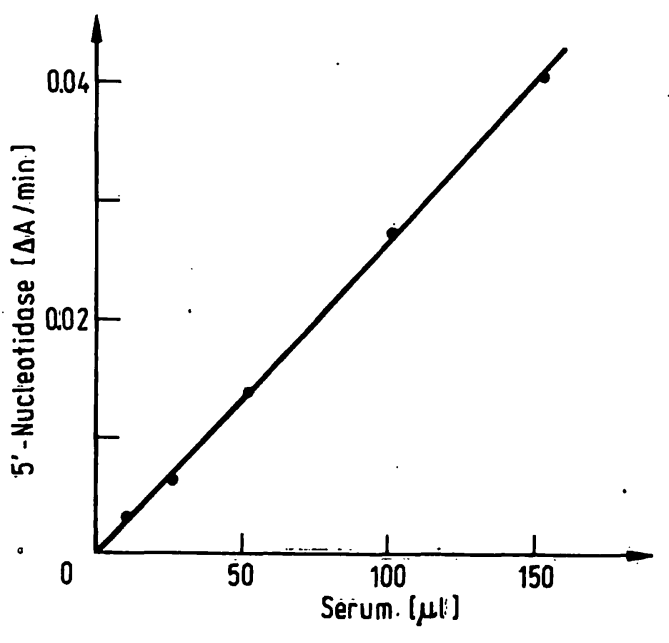

Fig. 4. Dependence of the absorbance change per minute at $334 \mathrm{~nm}$ on the amount of $S^{\prime}$-nucleotidase added. 


\section{Comparison of methods}

For comparison, we chose a commercially available test kit from Biomérieux, Nürtingen, which uses the liberation of phosphate from $5^{\prime}$-AMP as an indicator for $5^{\prime}$-nucleotidase activity. The $5^{\prime}$-nucleotidase activity is calculated from the amount of phosphate liberated in the presence and absence of nickel ions (tab. 5).

The correlation between our method and the commercially available method was examined by means of linear regression analysis; the resulting coefficient value of $r=0.88(n=6)$ indicated a poor correlation.

Tab. 5. Comparison of our method with a commercially available test kit, using the liberation of phosphate from 5 -AMP in the presence and absence of nickel ions according to Campbell (11) and Rieder (10).

\begin{tabular}{lll}
\hline Serum & $\begin{array}{l}\text { S'-Nucleotidase activity } \\
\text { (U/1) } \\
\text { Determined with } \\
\text { our method }\end{array}$ & $\begin{array}{l}\text { Determined with the } \\
\text { commercially } \\
\text { available method }\end{array}$ \\
\hline 1 & 1.89 & 8.56 \\
2 & 2.27 & 11.73 \\
3 & 2.89 & 12.29 \\
4 & 2.60 & 10.42 \\
5 & 1.47 & 5.40 \\
6 & 1.89 & 5.77 \\
\hline
\end{tabular}

The high values obtained for $5^{\prime}$-nucleotidase with the assay according to Campbell (11) and Rieder (10) may have several causes. One reason may be the higher temperature in the commercially available method $\left(37^{\circ} \mathrm{C}\right)$ compared with ours $\left(30^{\circ} \mathrm{C}\right)$.

Furthermore, not only $5^{\prime}$-nucleotidase, but alkaline phosphatase $(14,16)$ as well as other unspecific phosphatases, which are not yet well characterized, may be inhibited by nickel ions. In this way, the activity of alkaline phosphatase and unspecific phosphatases is diminished. An additional decrease of colour development is found in the presence of nickel ions, because of precipitation or complex-binding of phosphate by $\mathrm{Ni}^{2+}$; this is not controlled by an appropriate blank containing nickel but no sample.

Clinical application and reference values will be reported separately.

\section{Acknowledgement}

We thank Dr. C. J. Holloway (Zentrum Biochemie, Medizinische Hochschule Hannover) for his helpful assistence in the translation of the text and the firm of Janssen, Düsseldorf for the gift of the anthelmintic levamisole analogue R 8231, as well as the firm of Merck, Darmstadt for the gift of the anti-alkaline phosphatase from liver/bone.

\section{References}

1. Goldberg, D. M. (1973), Digestion 8, 87-99.

2. Drummond, G. I. \& Masanobu, Y. (1971), In: The Enzymes (Boyer, P. D. (ed.), (3 $3^{\text {rd }}$ ed.), vol. 4, pp. 337-341, Academic Press, New York.

3. Kim, N. K., Yasmineh, W. G., Treier, E. F., Goldman, A. \& Theologides, A. (1977), Clin. Chem. 23, 2034-2038.

4. Van der Hik, W., Persijn, J. P., Engelsmann, E. \& Riethorst, A. (1970), Clin. Biochem. 3, 59-80.

5. Persijn, J. P., Van der Hik, W. \& Engelsmann, E. (1972), this J. 10,77-85.

6. Gentry, M. K. \& Olson, R. A. (1975), Anal. Biochem. 64, $624-627$.

7. Glastris, B. \& Pfeiffer, S. E. (1974), In: Methods in Enzymology, (Fleischer, S. \& Packer, L., eds.), vol. 32, 124-131, Academic Press, New York.

8. Ipata, P. L. (1967), Anal. Biochem. 20, 30-36.

9. Bethune, V. G., Fleisher, M. \& Schwartz, M. K. (1972), Clin Chem. 18, 1525-1526.

10. Rieder, S. V. \& Otero, M. (1969), Clin. Chem. 15, 27-29.

11. Campbell, D. M. (1962), Biochem. J. 82, 34.

12. Baginski, E. S., Pappas, J. \& Marie, S. S. (1974), this J. 12, 241.

13. Baginski, E. S., Slawa Suchocha, M., Epstein, E. \& Bennie, Z. (1977), Ann. Clin. Lab. Sci. 7, 469-478.

14. El-Aaser, A. A. \& El-Merzabani, M. M. (1975), this J. 13, $453-459$.

15. Hill, P. G. \& Sammonds, H. G. (1966), Clin. Chem. Acta 13, $739-745$

16. Beckmann, J., Leybold, K. \& Weisbecker, L. (1969), this J. $7,18-24$.

17. Beckmann, J. \& Beckmann, O. (1971), this J. 9, 277.

18. Belfield, A. \& Goldberg, D. M. (1969), Clin. Chem. 15, 931-939.
19. Belfield, A., Ellis, G. \& Goldberg, D. M. (1970), Clin. Chem. $16,396-401$.

20. Persijn, J. P. \& van der Slik, W. (1970), $7^{\text {th }}$ Int. Congr. Clin. Chem., Geneva/Evian 1969; vol. 2, Clin. Enzymol., 108-112 (Karger, Basel).

21. Persijn, J. P., van der Slik, W., Timmer, C. J. \& Reijntjes, C. M. $(1970)$, this J. 8, 398-402.

22. Zygowicz, E. R., Sunderman, F. W. \& Horak, E. (1977), Clin. Chem. 23, 1171.

23. Zygowicz, E. R., Sunderman, F. W., Horak, E. \& Dooley, J. F. (1977), Clin. Chem. 23, 2311.

24. Arkesteijn, C. L. (1976), this J. 14, 155-159.

25. Bootsma, J., Wolthers, B. G. \& Groen, A. (1972), Clin. Chim. Acta 41, 219-222.

26. Ellis, G., Belfield, A. \& Goldberg, D. M. (1970), $7^{\text {th }}$ Int. Congr. Clin. Chem., Geneva/Evian, 1969, vol. 2, Clin. Enzymol., 95-107 (Karger, Basel).

27. Ellis, G. \& Goldberg, D. M. (1972), Anal. Letters 5, 65-73.

28. Ismail, A. \& Williams, D. G. (1974), Clin. Chim. Acta 55, 211-216.

29. Fioretti, E., Caulini, G., Magni, G. \& Felicioli, R. A. (1972), Ital. J. Biochem. 21, 102-112.

30. Haeckel, R. \& Heinz, F. (1975), this J. 13, 244.

31. Haeckel, R. (1976), this J. 14, 101-107.

32. Beushausen, Th. W. (1979), Dissertation, Med. Hochschule Hannover.

33. Heinz, F., Reckel, S. \& Kalden, J. R. (1979), Enzyme 24. 239-255.

34. Heinz, F., Reckel, S., Pilz, R. \& Kalden, J. R. (1980), Enzyme $25,44-55$.

35. Walter, K. \& Schütt, C. (1974), In: Methoden der enzymatischen Analyse (Bergmeyer, H. U. ed.) pp. 893-897, $3^{\text {rd }}$ cdition, Verlag Chemie, Weinheim. 
36. Bodansky, O. \& Schwartz, K. M. (1968), Adv. Clin. Chem. $11,277-238$.

37. Pilz, R. (1981), Dissertation Med. Hochschule Hannover

38. Schwartz, M. \& Bodansky, O. (1964), Amer. J. Clin. Pathol. $24,572-580$.

39. Bodansky, O. \& Schwartz, K. M. (1963), J. Biol. Chem. 238, 3420-3427.

40. Hurwitz, M. Y. \& Edstrom, R. D. (1978), Anal. Biochem. 84, 246-250.
41. Belfield, A. \& Goldberg, D. M. (1970), Clin. Biochem. 3, 105-110.

42. Belfield, A. \& Goldberg, D. M. (1971), this J. 9, 197-200.

43. Borgers, M. (1973), J. Histochem. Cy tochem. 21, 812-824.

44. Van Belle, H. (1972), Biochim. Biophys. Acta 289, 158168.

Prof. Dr. Fritz Heinz

Zentrum Biochemie -4310-

Medizinische Hochschule Hannover

Karl-Wiechert-Allee 9

D-3000 Hannover 61 